\title{
Comparative Counts of Bacterial Nuclei Made Visible by Four Different Techniques
}

\author{
By B. A. BRIDGES ANd R. J. MUNSON \\ Medical Research Council, Radiobiological Research Unit, \\ Harwell, Didcot, Berkshire
}

(Received 4 December 1964)

\begin{abstract}
SUMMARY
Four different methods were used to make visible the nuclei of Escherichia coli strains B and WP 2, and Bacillus subtilis. They were: (1) Giemsa staining after acid hydrolysis; (2) fluorescence microscopy after acridine orange treatment; (3) acriflavine staining and phase-contrast microscopy; (4) phase-contrast observations with high refractive index mounting medium (polyvinylpyrrolidone). Statistical analyses showed small but significant differences in nuclear counts between the methods. Methods 1 and 2 were somewhat preferable to methods 3 and 4 in that 1 and 2 were easier to score and there was less difference between observers. It was calculated that a single mean nuclear count, by any observer or method, based on 200 scored bacteria should 19 times out of 20 estimate the 'true' mean nuclear number of $\boldsymbol{E}$. coli wP 2 to within about $\pm 7.5 \%$ and of $B$. subtilis and $E$. coli B to within about $\pm 12 \%$. By increasing the number of bacteria counted and the number of methods used these limits could be appreciably decreased.
\end{abstract}

\section{INTRODUCTION}

In recent years a number of experiments designed to follow the fate of heritable changes in the bacterial genome during their subsequent segregation have been reported, for example after mutation induction (Ryan, Fried \& Schwartz, 1954; Munson \& Bridges, 1964) and also after recombination (Tomizawa, 1960). To interpret the observed patterns of segregation it was necessary to know the average number of nuclei/bacterium in the initial population and, if possible, the proportions of bacteria containing $1,2,3,4, \ldots$ nuclei. To do this most workers have used modifications of the Feulgen staining technique, in which fixed bacteria are exposed to a mild acid hydrolysis which results in the liberation of aldehyde groups on the DNA. These are made to undergo a Schiff reaction and the DNA becomes stained a very pale pink. As it is known that the RNA does not stain after such hydrolysis (Vendrely \& Lipardy, 1946), other less specific stains have been used, Giemsa being the most favoured because of the greater intensity of staining (Piekarski, 1937, 1940; Robinow, 1942, 1944). The staining reaction with Giemsa after hydrolysis is abolished when the bacteria are treated with DNA-ase (Munson \& Maclean, 1961). These staining methods are not noted for their ease and simplicity, success being critically dependent upon the durations of the fixation and hydrolysis stages. Other methods of making nuclei visible have therefore been sought.

The property of nucleic acids of fluorescing under ultraviolet or violet radiation 
when treated with certain acridine dyes was utilized by Krieg (1954) and by Anderson, Armstrong \& Niven (1959). They found that under certain conditions the DNA (nuclei) of Escherichia coli could be made to fluoresce green and the cytoplasm red.

The Feulgen-positive areas in fixed bacteria were shown by Tulasne (1949), Stempen (1950) and Mason \& Powelson (1956) to coincide with areas of low refractive index within the cytoplasm of unfixed bacteria. These are normally only faintly visible with phase-contract microscopy but Barer, Ross \& Tkaczyk (1953) were able to increase the contrast by altering the refractive index of the medium in which the bacteria were mounted. Mason \& Powelson (1956) successfully used gelatin, and Schaechter, Williamson, Hood \& Koch (1962) polyvinylpyrrolidone (hereafter PVP) as highly refractive mounting media with living cells. We have found that the contrast in water-mounted unfixed preparations may also be enhanced by lightly staining with acriflavine or acridine orange. This is presumably due to changes in refractive index within the cell, possibly by differential binding of the dye to nuclear and cytoplasmic material.

In the present work we have compared statistically the mean numbers of nuclei/ bacterium in populations of bacteria, as found by using four different techniques representative of the known microscopic methods of making nuclei visible.

\section{METHODS}

Preparation of smears. The starting material for all the techniques used was a smear obtained by allowing organisms suspended in their growth medium to dry on a glass slide in a $37^{\circ}$ incubator. These dried smears were stable for many hours. This enabled preparations from the same specimen to be observed by different techniques throughout the working day. The organisms used were Escherichia coli strains $\mathrm{B}$ and $\mathrm{B} / \mathrm{r}$ WP 2 growing exponentially at $37^{\circ}$ in glucose + salts medium (in the case of strain WP 2 with a tryptophan supplement $6 \mu \mathrm{g} . / \mathrm{ml}$. ), and Bacillus subtilis growing exponentially in Oxoid nutrient broth at $37^{\circ}$.

Giemsa-staining technique. The smear was fixed for $3 \mathrm{~min}$. in osmium tetroxide vapour followed by $5 \mathrm{~min}$. in Schaudinn's alcohol at $37^{\circ}$ and then stored in $70 \%$ $(\mathrm{v} / \mathrm{v})$ ethanol in water. It was then hydrolysed, for $5 \mathrm{~min}$. in the case of Escherichia coli strains or for $23 \mathrm{~min}$. in the case of Bacillus subtilis, in $\mathrm{N}$-hydrochloric acid at $57-58^{\circ}$, washed in buffered water $\left(0.0908\right.$ g. $/ 1 . \mathrm{KH}_{2} \mathrm{PO}_{4}, 0 \cdot 1188 \mathrm{~g}$. $/ \mathrm{l} . \mathrm{Na}_{2} \mathrm{HPO}_{4} \cdot \mathbf{2 H}_{2} \mathrm{O}$, pH 6.98) and stained with $10 \%$ aqueous Giemsa solution (G. T. Gurr, London) for $25 \mathrm{~min}$. at $\mathbf{3 7} 7^{\circ}$. After further washing, water was removed by careful blotting and the preparations observed directly through immersion oil by bright field microscopy.

Fluorescence with acridine orange technique. One drop of aqueous 1/5000 acridine orange (G. T. Gurr, London) and one drop of sodium hydroxide + acetic acid buffer $(0 \cdot 6 \mathrm{~N}$-acetate, $\mathrm{pH} 4 \cdot 5)$ were placed on the slide for a few seconds and then gently ashed off with a further quantity of $\mathrm{pH} 4.5$ buffer. A coverslip was placed over the wet preparation and the nuclei observed by fluorescence microscopy. The fluorescence of some preparations faded fairly rapidly under illumination so that frequent changes of field were necessary.

Acriflavine phase-contrast technique. The unfixed smear was stained for $1 \mathrm{~min}$. with a drop of $0.01 \%(w / v)$ acriflavine (British Drug Houses Ltd.), gently washed, 
mounted in distilled water under a coverslip and observed by phase-contrast microscopy.

Polyvinylpyrrolidone phase-contrast technique. The unfixed smear was mounted in $25 \%(\mathrm{w} / \mathrm{v})$ polyvinylpyrrolidone (PVP) in $0.5 \% \mathrm{NaCl}$ solution and observed through a coverslip by phase-contrast microscopy.

Microscopy. The same microscope (Cooke 2000 binocular) was used for all observations. For bright field and fluorescence microscopy a bright-field condenser of N.A. 1.0 and $\times 95$ objective of N.A. $1 \cdot 3$ were used. For fluorescence microscopy the primary filtration was by $4 \mathrm{~cm}$. of a $2 \%$ ammoniacal copper sulphate solution or two thicknesses of Ilford 304 filter, and the secondary (eyepiece) filters were Ilford 110 minus blue. The light source was a high-pressure mercury vapour lamp.

Phase-contrast observations were made with a condenser of N.A. $1 \cdot 0$ and $\times \mathbf{9 5}$ phase objective of N.A. 1.3. The combination of eyepieces and binocular body gave an equivalent magnification of $\times 15$.

Scoring procedure. Each preparation was scored independently by two observers. Several fields were scanned with the intention of scoring every bacterium within each field. Bacteria were recorded as having 1, 2, 3, 4 or more nuclei or as being unscorable and each observer scored about 230 bacteria per preparation. The number of unscorable bacteria in the first 200 observed was noted and the statistical analyses were based on the first 200 scorable bacteria recorded by each observer. The results were analysed for differences between treatments and between observers.

\section{RESULTS}

There were relatively few unscorable bacteria and their omission from the analyses is unlikely to have contributed any significant bias to the results. It is clear from the data in Tables 1-4 that the four methods gave similar distributions of bacteria with

Table 1. Nuclear counts of a population of Escherichia coli WP 2

(1st series) by two observers using four different methods

\begin{tabular}{|c|c|c|c|c|c|c|c|c|}
\hline \multirow[b]{2}{*}{ Method* } & \multirow[b]{2}{*}{ Observer } & \multirow{2}{*}{$\begin{array}{l}\text { Propor- } \\
\text { tion of } \\
\text { unscorable } \\
\text { bacteria } \\
(\%)\end{array}$} & \multicolumn{4}{|c|}{$\begin{array}{l}\text { Number out of } 200 \text { scorable } \\
\text { bacteria with } n \text { nuclei }\end{array}$} & \multirow{2}{*}{\multicolumn{2}{|c|}{$\begin{array}{l}\text { Mean nuclear } \\
\text { number }\end{array}$}} \\
\hline & & & $n=1$ & 2 & 3 & 4 & & \\
\hline $\mathbf{A F}$ & $\begin{array}{l}\text { BAB } \\
\text { RJM }\end{array}$ & $\begin{array}{l}0 \cdot 5 \\
5 \cdot 5\end{array}$ & $\begin{array}{l}110 \\
131\end{array}$ & $\begin{array}{l}89 \\
67\end{array}$ & $\begin{array}{l}1 \\
1\end{array}$ & $\begin{array}{l}0 \\
1\end{array}$ & $\begin{array}{l}1 \cdot 45 \pm 0 \cdot 04 \\
1 \cdot 36 \pm 0 \cdot 04\end{array}$ & \multirow{4}{*}{$1 \cdot 43 \pm 0.02$} \\
\hline AO & $\begin{array}{l}\text { BAB } \\
\text { RJM }\end{array}$ & $\begin{array}{l}8 \cdot 5 \\
3\end{array}$ & $\begin{array}{r}109 \\
99\end{array}$ & $\begin{array}{r}90 \\
100\end{array}$ & $\begin{array}{l}1 \\
1\end{array}$ & $\begin{array}{l}0 \\
0\end{array}$ & $\begin{array}{l}1 \cdot 46 \pm 0 \cdot 04 \\
1 \cdot 51 \pm 0 \cdot 04\end{array}$ & \\
\hline Giemsa & $\begin{array}{l}\text { BAB } \\
\text { RJM }\end{array}$ & $\begin{array}{l}5 \\
1 \cdot 5\end{array}$ & $\begin{array}{l}126 \\
119\end{array}$ & $\begin{array}{l}73 \\
81\end{array}$ & $\begin{array}{l}1 \\
0\end{array}$ & $\begin{array}{l}0 \\
0\end{array}$ & $\begin{array}{l}1 \cdot 38 \pm 0 \cdot 03 \\
1 \cdot 41 \pm 0.03\end{array}$ & \\
\hline PVP & $\begin{array}{l}\text { BAB } \\
\text { RJM }\end{array}$ & $\begin{array}{l}5 \cdot 5 \\
0\end{array}$ & $\begin{array}{r}97 \\
124\end{array}$ & $\begin{array}{r}103 \\
75\end{array}$ & $\begin{array}{l}0 \\
1\end{array}$ & $\begin{array}{l}\mathbf{0} \\
\mathbf{0}\end{array}$ & $\begin{array}{l}1 \cdot 51 \pm 0.04 \\
1.39 \pm 0.04\end{array}$ & \\
\hline
\end{tabular}

* $\mathrm{AF}=$ acriflavine phase-contrast $; \mathbf{A O}=$ acridine orange fluorescence; $\mathbf{P V P}=$ polyvinylpyrrolidone.

respect to nuclear number. In all except one instance, however, such differences as were observed were significant by the $\chi^{2}$ test (Table 5). With the Giemsa and fluorescence with acridine orange techniques the observers did not differ 
significantly in 7 out of 8 estimations; this is probably a reflexion of the clarity of the microscopic picture obtained with these techniques. The phase-contrast acriflavine and polyvinylpyrrolidone (PVP) techniques yielded preparations which were estimated differently by observers in 6 out of 8 cases, a result which reflects the subjective difficulty in scoring which was especially noticeable with PVP preparations.

Table 2. Nuclear counts of a population of Escherichia coli $W_{P} 2$

(2nd series) by two observers using four different methods

\begin{tabular}{|c|c|c|c|c|c|c|c|}
\hline \multirow[b]{2}{*}{ Method* } & \multirow[b]{2}{*}{ Observer } & \multirow{2}{*}{$\begin{array}{c}\text { Propor- } \\
\text { tion of } \\
\text { unscorable } \\
\text { bacteria } \\
(\%)\end{array}$} & \multicolumn{4}{|c|}{$\begin{array}{l}\text { Number out of } 200 \text { scorable } \\
\text { bacteria with } n \text { nuclei }\end{array}$} & \multirow{2}{*}{$\begin{array}{l}\text { Mean nuclear } \\
\text { number }\end{array}$} \\
\hline & & & $n=1$ & 2 & 3 & 4 & \\
\hline $\mathbf{A F}$ & $\begin{array}{l}\text { BAB } \\
\text { JL }\end{array}$ & $\begin{array}{l}5 \cdot 5 \\
9\end{array}$ & $\begin{array}{r}56 \\
103\end{array}$ & $\begin{array}{r}136 \\
79\end{array}$ & $\begin{array}{r}7 \\
18\end{array}$ & $\begin{array}{l}\mathbf{1} \\
\mathbf{0}\end{array}$ & \multirow{4}{*}{$1 \cdot 66 \pm 0 \cdot 03$} \\
\hline AO & $\begin{array}{l}\text { BAB } \\
\text { JL }\end{array}$ & $\begin{array}{l}1 \\
0\end{array}$ & $\begin{array}{l}70 \\
87\end{array}$ & $\begin{array}{l}128 \\
111\end{array}$ & $\begin{array}{l}2 \\
2\end{array}$ & $\begin{array}{l}0 \\
0\end{array}$ & \\
\hline Giemsa & $\begin{array}{l}\text { BAB } \\
\text { JL }\end{array}$ & $\begin{array}{l}0 \cdot 5 \\
7\end{array}$ & $\begin{array}{l}67 \\
89\end{array}$ & $\begin{array}{l}129 \\
107\end{array}$ & $\begin{array}{l}2 \\
4\end{array}$ & $\begin{array}{l}\mathbf{2} \\
\mathbf{0}\end{array}$ & \\
\hline PVP & BAB & 9 & 62 & 133 & 4 & 1 & \\
\hline & JL & 11 & 68 & 130 & 2 & 0 & $1 \cdot 67 \pm 0 \cdot 0^{3}$ \\
\hline
\end{tabular}

Differences which are apparent in the distribution analyses are much less obvious in the mean nuclear numbers. When the latter are considered as a sample of a population centred around a mean value, the most probable overall mean value can be calculated and also the distribution of the individual estimations. If, for a given strain of bacteria, the 'true' mean nuclear number is $m$, and the mean nuclear numbers estimated by different observers and different methods are regarded as random observations from a normally distributed population of possible estimates of $m$, then an overall estimate of $m$ (with standard error) can be obtained, and also a confidence interval for $m$ given. The results show that a single mean nuclear count, by any observer or method, based on 200 scored bacteria, would 19 times out of 20 estimate $m$ to within about $\pm 7.5 \%$ in the case of Escherichia coli wP 2 or about $\pm 12 \%$ in the case of Bacillus subtilis and $E$. coli B. The corresponding $95 \%$ confidence limits for the overall estimates of $m$ (from data by both observers and all four methods) were $\pm 3.6 \%$ and $\pm 5.7 \%$.

\section{DISCUSSION}

It is apparent from the quantitative data that all four methods made visible the same objects within the bacteria. It is fairly certain that the Giemsa and acridine orange fluorescence techniques make visible DNA, and the objects seen with the phase-contrast techniques are known to behave during the division cycle as one would expect of genetic material (Schaechter et al. 1962). There is thus little doubt that, in strains in which the nuclear material exists as a discrete body, it is possible to make visible and estimate with reasonable precision the number of such nuclei in a given population.

The easiest to score were Giemsa preparations, where dark nuclei were seen in a 


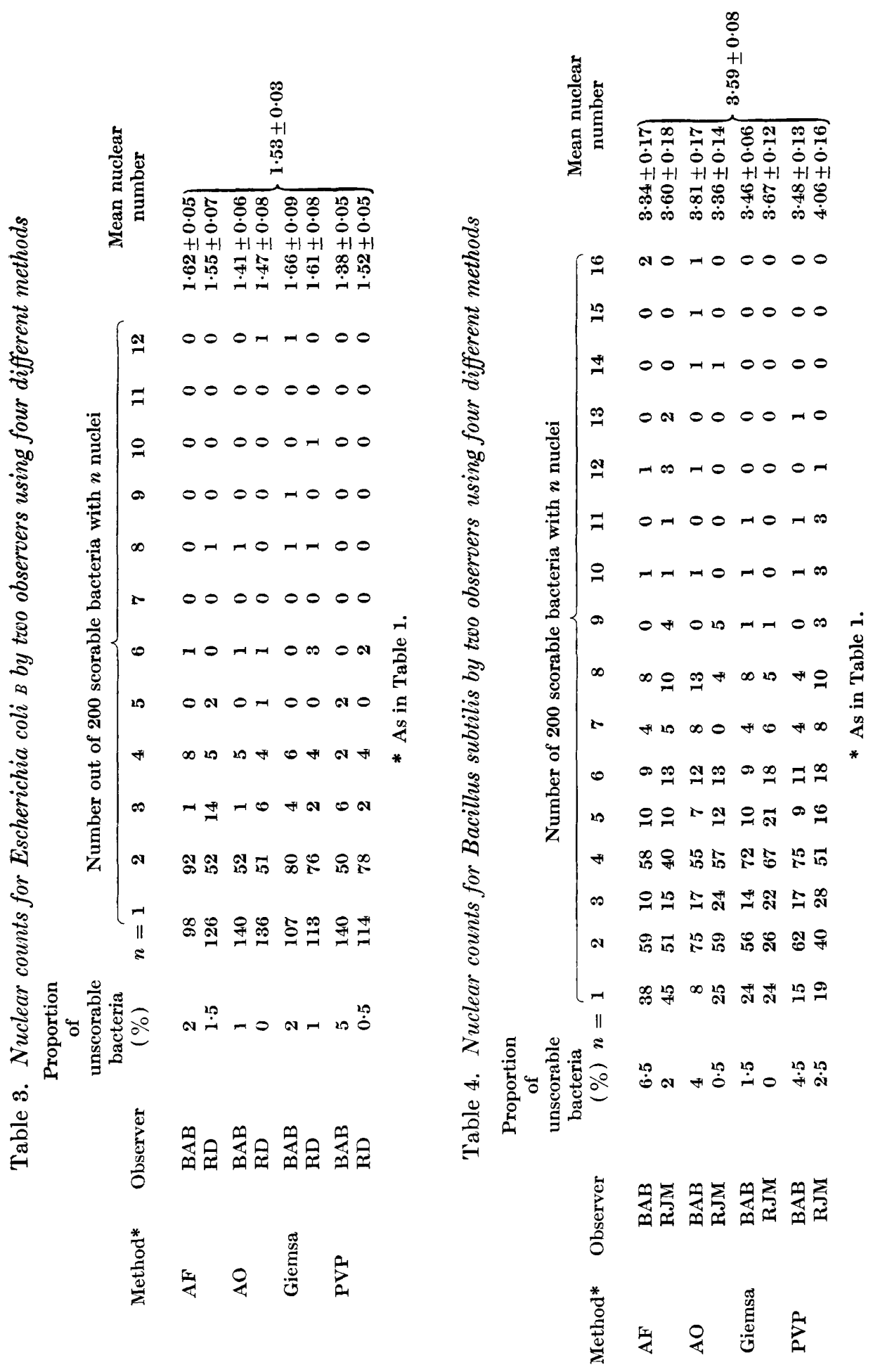


Table 5. Probability that the differences in observed distributions are due to chance

\begin{tabular}{|c|c|c|c|c|c|c|}
\hline \multirow[b]{2}{*}{ Series } & \multicolumn{4}{|c|}{ Between observers } & \multicolumn{2}{|c|}{ Between methods } \\
\hline & $\begin{array}{l}\text { AF } \\
(\%)\end{array}$ & $\begin{array}{l}\text { AO } \\
(\%)\end{array}$ & $\begin{array}{c}\text { Giemsa } \\
(\%)\end{array}$ & $\begin{array}{c}\text { PVP } \\
(\%)\end{array}$ & $\begin{array}{c}\text { BAB } \\
(\%)\end{array}$ & $\begin{array}{c}\text { Other } \\
\text { observer } \\
(\%)\end{array}$ \\
\hline Escherichia coli wP 2 (1st series) & 5 & $>5$ & $>\mathbf{5}$ & 1 & $\mathbf{5}$ & 1 \\
\hline$E$. coli wP 2 (2nd series) & $0 \cdot 1$ & $>5$ & $>5$ & $>5$ & $>\mathbf{5}$ & $0 \cdot 1$ \\
\hline E. coli $\mathbf{B}$ & $0 \cdot 1$ & $>5$ & $>5$ & 1 & $0 \cdot 1$ & $0 \cdot 1$ \\
\hline Bacillus subtilis & $>\mathbf{5}$ & $0 \cdot 1$ & $>5$ & $0 \cdot 1$ & $\mathbf{2} \cdot \mathbf{5}$ & $0 \cdot 1$ \\
\hline
\end{tabular}

pink cytoplasm. The technique was tedious, however, and very occasionally the results were so poor that scoring was impossible. The acridine orange fluorescent preparations were readily made and fairly easy to score once dark adaptation of the eyes had been achieved (usually by means of a velvet hood). Theoretically, resolution with fluorescent light should be slightly inferior to that with transmitted light, and in the former case this might have resulted in the underestimation of newly divided nuclei. There was, however, no indication of this in our results. The acriflavine phase-contrast technique was equally quick and required no dark adaptation. Nuclei appeared as small light areas in a dark cytoplasm and, although this made recognition more difficult than with the reverse contrast, completely unscorable preparations were extremely rare.

The polyvinylpyrrolidone (PVP) preparations were by far the most difficult to score. Not only did the bacteria become detached from the slide but the contrast between nuclear and cytoplasmic regions was not great. In the published photographs of Schaechter et al. (1962) the image had been reversed and the contrast considerably enhanced by photographic means. Other workers had reported that the concentration of PVP (or gelatin) was critical but we did not find this to be so. The PVP (or gelatin) method has the important advantage that it is the only one which permits the observation of nuclei in living organisms.

It is clear from the data given here that there is little to choose between the four methods as far as the quantitative estimation of nuclear numbers is concerned. Other factors might, therefore, determine the most suitable method for a given system in any future work. The differences between individual observers could probably have been decreased by scoring nuclei from photographs, but the loss of resolution for slightly out of focus nuclei appeared to outweigh the advantages of this procedure.

We thank Mr J. Law and Miss Rachel Dennis for participating in the scoring and Mr D. Papworth for the statistical analysis. 


\section{REFERENCES}

Anderson, E. S., Armstrong, J. A. \& Niven, J. S. F. (1959). Fluorescence microscopy: observation of virus growth with aminoacridines. In Virus Growth and Variation. Symp. Soc. gen. Microbiol. 9, 224.

Barer, R., Ross, K.F.A. \& Tkaczyк, S. (1953) Refractometry of living cells. Nature, Lond. 171, 720 .

KreIG, A. (1954). Nachweis von Kernäquivalenten in Zyanophyzeen. Experientia, 10, 204.

Mason, D. J. \& Powelson, D. M. (1956). Nuclear division as observed in live bacteria by a new technique. J. Bact. 71, 474.

Munson, R. J. \& Bridges, B. A. (1964). Segregation of radiation-induced mutations in E. coli. Nature, Lond. 203, 270.

Munson, R. J. \& Maclean, F. I. (1961). The nature and radiation sensitivity of the long forms of Escherichia coli strain в/r. J. gen. Microbiol. 25, 29.

Piekarski, G. (1937). Cytologische Untersuchungen an Paratyphus-und Colibakterien. Arch. Microbiol. 8, 428.

Piekarski, G. (1940). Über kernähnliche Strukturen bei Bacillus mycoides Flügge. Arch. Microbiol. 11, 406.

Robinow, C. F. (1942). A study of the nuclear apparatus of bacteria. Proc. roy. Soc. B, 130, 299.

Robinow, C. F. (1944). Cytological observations of Bact. coli, Proteus vulgaris and various aerobic spore-forming bacteria with special reference to the nuclear structures. $J$. Hyg., Camb. 43, 413.

Ryan, F. J., Fried, P. \& Schwartz, M. (1954). Nuclear segregation and the growth of clones of bacterial mutants induced by ultraviolet light. J. gen. Microbiol. 11, 380.

Schaechter, M., Williamson, J. P., Hood Jun., J. R. \& Koch, A. L. (1962). Growth, cell and nuclear divisions in some bacteria. J. gen. Microbiol. 29, 421.

Stempen, H. (1950). The demonstration of the chromatinic bodies of Escherichia coli and Proteus vulgaris with the aid of the phase contrast microscope. J. Bact. 60, 81.

Tomizawa, J. (1960). Genetic structure of recombinant chromosomes formed after mating in Escherichia coli n 12. Proc. natn. Acad. Sci., U.S.A. 46, 91.

Tulasne, R. (1949). Mise en évidence du noyau chez les bactéries vivantes grâce au dispositif à contraste de phase. C.r. hebd. Séanc. Acad. Sci., Paris, 229, 561.

Vendrely, R. \& Lipardy, J. (1946). Acides nucléiques et noyaux bactériens. C.r. hebd. Séanc. Acad. Sci., Paris, 223, 342. 